\title{
An Observational Study on Early-Lactation Metabolic Profiles in Swedish Organically and Conventionally Managed Dairy Cows
}

\author{
N. Fall,, ${ }^{1}$ Y. T. Gröhn,† K. Forslund, ${ }^{*}$ B. Essen-Gustafsson, ${ }^{*}$ R. Niskanen, $\ddagger$ and U. Emanuelson* \\ *Department of Clinical Sciences, Swedish University of Agricultural Sciences, PO Box 7054, SE-750 07 Uppsala, Sweden \\ †Department of Population Medicine and Diagnostic Sciences, Section of Epidemiology, College of Veterinary Medicine, Cornell University, \\ Ithaca, NY 14853 \\ ¥National Food Administration, PO Box 622, SE-751 26 Uppsala, Sweden
}

\section{ABSTRACT}

The aim of this observational study was to compare indicators of energy balance in early lactation in organically managed dairy cows (OMC) and conventionally managed dairy cows (CMC) under field conditions. The diets of $\mathrm{OMC}$ and $\mathrm{CMC}$ differ as a consequence of the rules and principles of organic dairy farming. The study was based on clinical examinations and blood samples from cows within the range from 2 wk prepartum to 6 wk postpartum, collected from 20 organic and 20 conventional dairy farms with 3 visits at each farm. The farms were located in a southeastern area of Sweden and ranged in size from 45 to 120 cows. The blood parameters selected to reflect energy metabolism were nonesterified fatty acids, B-hydroxybutyrate, glucose, and insulin. At clinical examination body condition score was registered. The shape of the lactation curve in early lactation was modeled to assess potential differences that could explain the blood parameter profiles. The conventionally managed cows increased their milk yield faster than OMC within the first 2 wk of lactation. Blood nonesterified fatty acid concentrations were similar between the management types, but with a tendency of lesser concentrations in OMC, primarily in early lactation. Postcalving B-hydroxybutyrate concentrations were constantly lesser in OMC during the first $6 \mathrm{wk}$ of lactation. An interaction between season and insulin concentration necessitated stratification on season. During spring the profiles overlapped, but there was a significant difference in the first $4 \mathrm{~d}$ postcalving, when organically managed cows had greater insulin concentrations and in d 30 to 34 when conventionally managed cows had greater insulin concentrations. During fall the profiles overlapped completely and there was no significant difference at any point in time. Glucose concentrations tended to decrease

\footnotetext{
Received February 14, 2008.

Accepted April 15, 2008.

${ }^{1}$ Corresponding author: Nils.Fall@kv.slu.se
}

slightly postcalving followed by a gradual elevation to a concentration just under the precalving concentration during the study period. Body condition scores decreased slightly over the study period. No differences were found between the management types with regard to glucose concentrations or registered body condition score. In conclusion, the OMC did not show a greater extent of mobilization of body tissue than CMC as expressed by our study variables. Hence, OMC adjusted the production amount according to feed intake.

Key words: organic dairy cow, metabolic profile

\section{INTRODUCTION}

During the last decades organic farming has developed from a subcultural grass roots movement into an established part of modern agriculture, with dairy production representing an important branch. In areas where cows are housed during a significant part of the year, the composition of feed is one of the major differences between organic and conventional dairy farming. According to European Union legislation (Council of the European Communities, 1991) organically managed dairy cows (OMC) must be fed at least $95 \%$ organically produced feed, no genetically modified products may be used, and the total daily dry matter proportion of concentrate should not exceed $50 \%$ during the first $3 \mathrm{mo}$ of lactation and thereafter not more than $40 \%$. In consequence, the roughage/concentrate ratio often becomes greater in organic than in conventional management. Furthermore, there are major differences between organic and conventional management regarding the use of antibiotic and chemotherapeutic treatments and in handling of the animals. Guidelines from the International Federation of Organic Agriculture Movements and basic acts from the European Union are, however, interpreted and implemented somewhat differently in different countries. In Sweden, for instance, the organic regulations prescribe a doubled withdrawal period for delivery of milk after treatment with registered pharmaceuticals (compared with the one laid down by 
the Swedish National Food Administration), an antiparasite strategy without drugs, fresh milk for raising calves, access to regular exercise, and a prolonged grazing season.

In early lactation energy intake is usually smaller than energy requirements, which results in negative energy balance and hence mobilization of body reserves. There is a possibility that OMC are at a greater risk of negative energy balance than conventionally managed dairy cows (CMC) in consequence of the restrained use of concentrates in OMC (Hardeng and Edge, 2001). One reason for this argument is that they share the same genetic potential for milk production, at least under Swedish circumstances. Conversely, smaller milk yields have previously been shown in organic dairy farming (Hamilton et al., 2002; Roesch et al., 2005) and can possibly reduce the risk of negative energy balance in OMC. Mobilization of body reserves primarily involves body fat and results in elevated serum concentrations of NEFA and BHBA (Ingvartsen et al., 2003; Kokkonen et al., 2005; van Knegsel et al., 2007). Other blood metabolites that indicate mobilization of body tissue are insulin and glucose (Vazquez-Anon et al., 1994; Grum et al., 1996; Butler et al., 2003). Those blood metabolites are therefore suitable for assessment of energy balance under field conditions. Body condition score is also considered to be an important clinical indicator of energy balance (Busato et al., 2002; Ingvartsen et al., 2003; Roesch et al., 2005).

Epidemiological studies of differences in energy metabolism between $\mathrm{OMC}$ and $\mathrm{CMC}$ are, however, scarce. In a study by Roesch et al. (2005) no differences in the blood metabolites NEFA, BHBA, or glucose were found around $30 \mathrm{~d}$ postpartum, nor were any differences found in BCS before or after calving, making the authors suggest that energy intake was not abnormal in any group. Another study by McNamara et al. (2003), however, not focusing on OMC versus CMC, but on high and low amounts of concentrate, showed significant differences in calculated energy balance between the groups, in which cows given low amounts of concentrate had more negative energy balance compared with cows given high amounts of concentrate. The cows were blood sampled 2 wk postpartum, and significant differences were found in blood glucose concentrations but not in NEFA or BHBA. A clinical manifestation of negative energy balance is ketosis, and it has previously been studied in OMC. Hamilton et al. (2002) found no signs of widespread clinical or subclinical ketosis, whereas Hardeng and Edge (2001) found markedly lesser occurrence of clinical ketosis in organic than conventional cows.

The objective of the present study was to assess differences in body tissue mobilization during early lacta- tion, indicating negative energy balance by comparing blood parameters and BCS between OMC and CMC.

\section{MATERIALS AND METHODS}

\section{Study Design, Herds, and Animals}

Forty herds, geographically located in a southeastern area of Sweden (Uppland, Sörmland, Östergötland, and Småland) were included in the study. The selection was done among herds with $>40$ cows participating in the Swedish Official Milk Recording Scheme (SOMRS) and not planning to close down their business before the beginning of 2007. Only organic farms that had produced milk according to the Swedish organic standards (http://www.krav.se) for $>2 \mathrm{yr}$, and in accordance with the rules, fed $95 \%$ organic feed and 5\% conventional feed were enrolled. All 52 eligible organic herds were asked to participate in the study, and 24 of them assented. By simple random selection, 156 farms of the eligible 283 conventional farms in the area were selected and asked to participate in the study, and 32 assented. By simple random sampling, 20 organic and 20 conventional of the assenting farms were selected for the study. Random selection of herds was done using computer generated random numbers. The herds were all visited 3 times. The first visit was made in the spring of 2005, the second in the fall of 2005, and the third visit in the spring of 2006. At each farm visit, cows and heifers that were within the period from $7 \mathrm{~d}$ before their predicted calving to $42 \mathrm{~d}$ after calving were eligible for inclusion in the study. If the number of animals in a herd meeting the inclusion criteria was $<12$, all of them were sampled. If there were $>12$ eligible cows in a herd, 12 of them were randomly selected using a random number table and included in the study.

\section{Data and Blood Sample Collection}

Information on the milk yield, breed composition, birth dates, and calving dates originated from the SOMRS and from questionnaires presented to the farmers at each visit. The information on milk yield was acquired from all SOMRS monthly test-milking occasions from calving to 44 DIM. A blood sample was drawn from the tail vein of all selected cows using $10-\mathrm{mL}$ evacuated tubes without anticoagulant. Blood glucose was analyzed "cow-side" using a glucometer (Precision Xceed, Abbott Diabetes Care). Tubes were transported at room temperature to a laboratory within $4 \mathrm{~h}$. Sera was then prepared by centrifugation $(2,000 \times g$ for 10 min) of clotted blood and stored at $-20^{\circ} \mathrm{C}$. Serum samples were analyzed at the Department of Clinical Pathology, Swedish University of Agricultural Sciences, 
Uppsala, Sweden, using commercial kits according to the manufacturer's instructions. Severely hemolyzed samples were excluded. Serum BHBA was measured by enzymatic quantification (B-Hydroxybutyrate LiquiColor Procedure No. 2440, Stanbio Laboratory, Boerne, TX). Serum NEFA were measured by a kininimine-red addition (NEFA C, ACS-ACOD method, Wako Chemicals GmbH, Neuss, Germany). Serum insulin was analyzed with a porcine insulin radioimmunoassay by the double antibody/PEG technique (Porcine Insulin RIA Kit, Linco Research, St. Charles, MO). The BCS was assessed according to a scale of 1 to 5 , in which 1 indicates severe undercondition and 5 indicates severe overcondition (Wildman et al., 1982).

\section{Statistical Analysis}

The major question in this study was whether BCS and serum concentrations of NEFA, BHB, insulin, or glucose differed between organically and conventionally managed cows. The possible relations between the main predictor management type and serum amounts of NEFA, BHBA, insulin, and glucose, and finally BCS were studied using linear mixed models with random herd effects. The rationale to study BCS, a discrete ordinal variable, using linear methodology was the normally distributed residuals from the model. The predictor variables in addition to management type were: parity, DIM, month of testing, housing type, and breed. The following initial model was used for all outcomes, in which Y represents outcome:

$$
\begin{aligned}
\mathrm{Y}= & \text { management type }+\mathrm{DIM}+\text { parity }+ \text { breed } \\
& + \text { month of testing }+ \text { type of housing. }
\end{aligned}
$$

Milk yield was considered an intervening variable and therefore left out of the models.

Parity was introduced as a categorical variable with 3 classes, first, second, and third or higher. Days in milk was introduced as categorical variable with 9 classes: cows before calving, then in 5-d intervals from calving to $34 \mathrm{~d}$ postcalving, and finally cows from 35 $\mathrm{d}$ to 43 postcalving. Month of testing was introduced as a categorical variable, with the following 5 classes: February, March, October, November, and December. One farm visit contributing 5 observations occurred on April 1, 2005, and these observations were classified as occurring in March. Housing system and breed were dichotomous variables characterized as loose or tie stall and Swedish Red (SRB) or Swedish Holstein (SH) breed. To obtain a homogeneous distribution of residuals, the outcomes NEFA, BHBA, and insulin were logtransformed with the base e. At each visit cows were randomly selected and the design was therefore of cross-sectional rather than longitudinal nature. Hence, we decided not to include cow as a repeated observation (825 cows contributed 1 , and only 74 cows out of 899 cows contributed 2 observations).

To display possible differences in the shapes and magnitudes of the lactation curves for milk yield between OMC and CMC, we developed 2 linear mixed models of milk yield with random herd effects, one for first-parity cows and one for older cows. The predictor variables in addition to management type included in the models were DIM, month of test-milking, housing type, and breed. Parity was included as a predictor in the model with older cows. Days in milk was classified in 5-d intervals starting at calving and proceeding to $45 \mathrm{~d}$ postcalving, hence adding up to 9 classes. Month of test-milking was introduced as a categorical variable with 9 classes: January, February, March, April, May, September, October, November, and December. Housing, breed, and parity were introduced in the same way as stated previously.

Spearman correlation coefficients were used to assess potential collinearity between the predictor variables. Model building in all models was done by backward stepwise elimination of main effects with $P<0.2$ ( $F$-test) as the exclusion and re-entering criterion. The variable management type was forced to remain in all the models because it was the predictor of main interest. All possible first-order interactions were subsequently added to the model, and the backward stepwise-elimination process was continued until all remaining effects had $P<0.05$. The interaction between management type and DIM was forced to stay in all models and comparisons of the estimates for each time point were done to establish possible differences that were not significant over the whole period. Confounding was assessed at each step of model development by inspecting changes in parameter estimates. Any changes $>20 \%$ were considered to indicate confounding.

Fit of the models was visually assessed by using plots of standardized residuals against the predicted values at the lowest hierarchical level and by using a normal probability plot in which the lowest level residuals were plotted against the quartiles. Influential observations were detected through examining Cook's distances and difference in fit (DFFITS). All statistical analyses were performed using SAS (SAS Institute, 2004).

\section{RESULTS}

\section{Descriptive Statistics}

The herds were of comparable size with a median of 60 (range from 41 to 105) and 58 (range from 40 to 
Table 1. Number of observations according to some characteristics of 899 lactating dairy cows in 20 organically and 20 conventionally managed Swedish farms studied to determine metabolic profiles

\begin{tabular}{|c|c|c|c|}
\hline Variable & & Organic & Conventional \\
\hline \multirow[t]{2}{*}{ Breed $^{1}$} & $\mathrm{SRB}$ & 309 & 337 \\
\hline & $\mathrm{SH}$ & 168 & 159 \\
\hline \multirow[t]{9}{*}{ DIM } & $<0$ & 55 & 55 \\
\hline & $0-4$ & 35 & 33 \\
\hline & $5-9$ & 35 & 52 \\
\hline & $10-14$ & 50 & 59 \\
\hline & $15-19$ & 59 & 53 \\
\hline & $20-24$ & 39 & 55 \\
\hline & $25-29$ & 51 & 45 \\
\hline & $30-34$ & 55 & 69 \\
\hline & $35-43$ & 98 & 75 \\
\hline \multirow[t]{5}{*}{ Month of testing } & February & 162 & 216 \\
\hline & March & 160 & 129 \\
\hline & October & 39 & 44 \\
\hline & November & 76 & 64 \\
\hline & December & 40 & 43 \\
\hline \multirow[t]{2}{*}{ Housing } & Loose stall & 339 & 208 \\
\hline & Tie stall & 138 & 288 \\
\hline \multirow[t]{3}{*}{ Parity } & 1 & 175 & 192 \\
\hline & 2 & 132 & 133 \\
\hline & $3+$ & 170 & 171 \\
\hline
\end{tabular}

${ }^{1} \mathrm{SRB}=$ Swedish Red breed and $\mathrm{SH}=$ Swedish Holstein breed.

122) lactating cows in organic and conventional herds, respectively. The official production figures from the herds differed between the management types ( $t$-test, $P<0.01)$ with an average milk production of 8,222 $(\mathrm{SD}=1,194) \mathrm{kg}$ and 9,171 $(\mathrm{SD}=885) \mathrm{kg}$ per cow and year in organic and conventional farms, respectively. Milk yield measured as the mean ECM/day of all testmilking occasions during the second and third months of lactation (Danell, 1982) for the cows included in the study was significantly less in OMC than in CMC ( $t$ test, $P<0.01$ ). The $\mathrm{OMC}$ averaged $32.5 \mathrm{~kg}$ of $\mathrm{ECM} / \mathrm{d}$ $(\mathrm{SD}=7.8)$, whereas $\mathrm{CMC}$ averaged $35.6 \mathrm{~kg}$ of $\mathrm{ECM} / \mathrm{d}$ $(\mathrm{SD}=7.5)$. Table 1 shows the distribution of cows over variables in the 2 herd types. The only variable with a somewhat skewed distribution was housing, in which loose stall was more frequent in organic (14 out of 20) than in conventional farms ( 7 out of 20 ). Consequently, the distribution was also skewed at cow level. Questionnaire results on feeding are shown in Table 2 and demonstrate a more roughage-based feed for $\mathrm{OMC}$ than CMC.

\section{Models}

The analyses of blood metabolites and BCS included 973 observations and the analysis of milk yield included 1,337 observations from a total of 899 cows. Differences between the management types for the outcome variables over time are presented in Tables 3 and 4 , and the corresponding lactation curves are presented in Figures 1 and 2. In early lactation there was a tendency of slower increase in milk yield for organically managed cows and overall a tendency of lower production. For first-parity cows there were significant differences in milk production between 5 and 9 DIM and $>34$ DIM, irrespective of breed. For older cows there were significant differences between 5 and 9 DIM and between 25 and 29 DIM for SRB cows, and between 10 and 14 DIM and 30 and 34 DIM for SH cows.

Organically managed cows showed lesser concentrations of NEFA in serum in early lactation. A borderline significance was shown in the interval between 5 and 9 DIM, and a significant difference in the interval between 10 and 14 DIM. Organically managed cows had lower concentration of BHBA during the whole lactation (Figure 2). The difference, however, was significant only in the periods between 10 and 14 DIM and 25 and 29 DIM. There was no clear difference in insulin concentration observed in February through March, except during 2 time intervals, one between 0 and 4 DIM and the other between 30 and 34 DIM. No differences were observed from October to December. No significant differences in serum glucose or BCS between the management types were found in this study. Estimated main effects included in the models are presented in Table 5. Based on residual analysis, the fit of the models were considered satisfactory and no influential observations were removed.

\section{DISCUSSION}

A compelling reason to conduct this type of study is a strong perception of consumers and politicians that organic management offers high standards for animal welfare and therefore delivers ethically produced, sound, and healthy products. Concern has been raised

Table 2. Dry matter roughage/concentrate ratio at 3 stages in lactation in 20 organic and 20 conventional Swedish dairy farms

\begin{tabular}{lcccccccc}
\hline & \multicolumn{3}{c}{ Organic } & & \multicolumn{3}{c}{ Conventional } \\
\cline { 2 - 3 } \cline { 7 - 9 } Time & Q1 & Median & Q3 & & Q1 & Median & Q3 \\
\hline Calving & 2.3 & 3.2 & 4.0 & & 1.8 & 2.0 & 2.4 \\
14 d in milk & 1.1 & 1.3 & 1.5 & & 0.7 & 0.9 & 1.1 \\
Maximum production & 1.0 & 1.1 & 1.3 & & 0.6 & 0.6 & 0.7 \\
\hline
\end{tabular}

${ }^{1} \mathrm{Q} 1$ represents the 25 th percentile and Q3 represents the 75 th percentile. 
Table 3. Estimated differences ${ }^{1}$ in milk yield $\left(\mathrm{kg}\right.$ of ECM d $\left.{ }^{-1}\right)$ of 899 cows from 20 organic and 20 conventional Swedish dairy farms studied to determine metabolic profiles

\begin{tabular}{|c|c|c|c|c|c|c|}
\hline \multirow{3}{*}{$\begin{array}{l}\text { Days } \\
\text { in milk }\end{array}$} & & & \multicolumn{4}{|c|}{ Parity $>1$} \\
\hline & \multicolumn{2}{|c|}{ Parity 1} & \multicolumn{2}{|c|}{$\mathrm{SR}^{2}$} & \multicolumn{2}{|r|}{$\mathrm{SH}^{3}$} \\
\hline & Est. & $95 \% \mathrm{CI}$ & Est. & $95 \% \mathrm{CI}$ & Est. & $95 \% \mathrm{CI}$ \\
\hline $0-4$ & 0.55 & $-2.90,4.01$ & 0.27 & $-4.34,4.88$ & -1.71 & $-8.92,5.51$ \\
\hline $5-9$ & $-6.61^{*}$ & $-9.56,-3.67$ & $-5.11^{*}$ & $-9.61,-0.62$ & -5.33 & $-11.22,0.57$ \\
\hline $10-14$ & -2.60 & $-5.64,0.44$ & -1.96 & $-6.23,2.31$ & $-7.43^{*}$ & $-13.01,-1.85$ \\
\hline $15-19$ & -2.10 & $-5.36,1.16$ & -1.71 & $-6.34,2.93$ & -5.89 & $-11.89,0.11$ \\
\hline $20-24$ & -0.66 & $-3.75,2.42$ & 0.04 & $-4.14,4.22$ & -3.64 & $-9.37,2.08$ \\
\hline $25-29$ & -0.37 & $-3.33,2.58$ & $-4.48^{*}$ & $-8.55,-0.41$ & -0.06 & $-5.85,5.73$ \\
\hline $30-34$ & -1.43 & $-4.76,1.90$ & -3.61 & $-7.99,0.77$ & $-6.73^{*}$ & $-12.96,-0.51$ \\
\hline $35-39$ & $-4.78^{*}$ & $-7.80,-1.77$ & -0.72 & $-5.17,3.73$ & -0.99 & $-7.50,5.52$ \\
\hline$>40$ & $-3.11^{*}$ & $-6.20,-0.03$ & -3.37 & $-7.98,1.23$ & $-8.24^{*}$ & $-14.37,-2.11$ \\
\hline
\end{tabular}

${ }^{1}$ Differences were obtained from linear mixed model analyses as the estimate for organic minus the estimate for conventional. A significant difference $(P<0.05)$ is denoted with *. The models included management type, days in milk, and where applicable, breed, month of testing, housing, and parity. CI = confidence interval.

${ }^{2}$ Swedish Red breed.

${ }^{3}$ Swedish Holstein breed.

whether a high roughage/concentrate ratio in organic dairy production can satisfy the high energy demands in early lactation. To our knowledge, only one previous study (Roesch et al., 2005) has addressed this concern. The present study is an attempt to bring more knowledge to this issue, and the results clearly show that OMC are not more prone to mobilize body tissue than CMC in early lactation. Furthermore, the present study suggests that OMC adapt their milk yield to feeding. Previous studies have observed lower milk yields in OMC than in CMC (Hardeng and Edge, 2001; Roesch et al., 2005; Hamilton et al., 2006). The milk yield curves in our study confirmed those findings and furthermore showed a tendency of slower increase in milk production in OMC than CMC after calving. The differences are in agreement with the study of Andersen et al. (2003) who concluded that cows in early lactation offered high amounts of concentrate have greater milk yields than those offered low amounts of concentrate.

Our investigation of parameters indicating mobilization of body tissue did not reveal any major differences between $\mathrm{OMC}$ and $\mathrm{CMC}$, which gives further support the earlier mentioned study by Roesch et al. (2005). If anything, our results indicate less tissue mobilization in OMC. The previous study by Roesch et al. (2005) on the possible effect of organic versus conventional management on the blood metabolites NEFA, BHBA, and glucose in early lactation showed no differences between organic and conventional management, thus concluding normal energy and nutrient intakes in both groups. The profiles for plasma NEFA, BHBA, insulin, and glucose concentrations in the present study were in accordance with previous experimental studies on conventional cows (Busato et al., 2002; Andersen et al., 2004; Nielsen et al., 2007), which gives confidence to our study design. The rise seen in blood NEFA concentration around parturition is considered to be partly due to hormonal changes and stress associated with termination of pregnancy and reduced dry matter intake (McNamara et al., 2003). Blood NEFA concentration, however, is often used as an indicator of negative energy balance and it is well documented that the NEFA profiles peak during the first 2 wk postpartum in consequence of endogenous fat mobilization, and then gradually returns to a steady state (Nielsen et al., 2007). Furthermore, it is known that the nadir of negative energy balance coincides with this time interval in high yielding cows (Jorritsma, 2003). A difference in energy balance between the management types would therefore be expected to be expressed as a difference in blood NEFA during the first 2 wk. In our study a tendency of lesser NEFA concentrations in OMC than in CMC during the first $2 \mathrm{wk}$ was observed, but it was only significant in the interval between 10 and $14 \mathrm{~d}$. Hence, taking NEFA into consideration there is a weak indication that OMC exhibit less negative energy balance than CMC in early lactation or at least body fat mobilization. Earlier experimental studies on the effect of feed with different roughage/concentrate ratios, however, have failed to show differences in plasma free fatty acids (such as NEFA) between treatment groups (Dhiman et al., 1991; Andersen et al., 2004). Those results would imply that no differences in NEFA as a consequence of different roughage/concentrate ratios were to be expected in our study. Adewuyi et al. (2006) demonstrated a relationship between low physical 

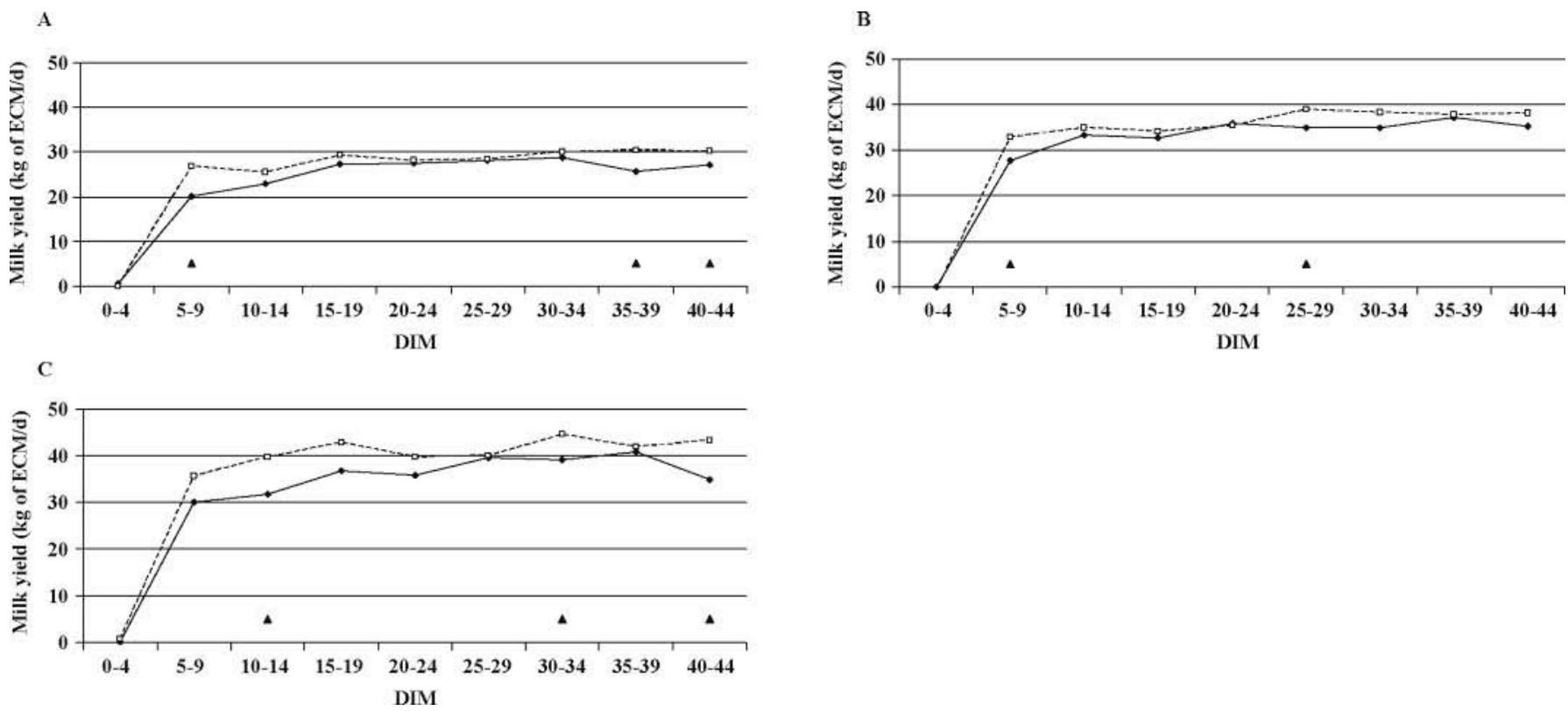

Figure 1. Least squares means estimated from linear mixed models of milk yield (kg of ECM/d) in 899 Swedish lactating dairy cows from 20 organically and 20 conventionally managed farms studied to determine metabolic profiles. A) first-parity cows, B) second-parity and older cows of Swedish Red breed, C) second-parity and older cows of Swedish Holstein breed. Organically managed cows are represented by solid lines (—-) and conventionally managed cows by dotted lines (---๑--). Time points with a significant difference $(P<0.05)$ are denoted with $\Delta$.

activity and high NEFA concentrations, which possibly could explain part of the difference in our study because OMC were kept in environments demanding physical activity to a greater extent than $\mathrm{CMC}$ and also the fact that regular physical activity is a condition to keep OMC in Sweden. On the other hand, housing type was not significant in the final model of NEFA.

An experimental study by McNamara et al. (2003) showed differences in calculated energy balance in cows given low and high amounts of concentrate in which cows given low concentrate had a more negative energy balance. Studying correlation coefficients between calculated energy balance and NEFA, and calculated energy balance and BHBA 2 wk postpartum, made the authors conclude that in their study BHBA was a more useful indicator of energy balance than NEFA or glucose. However, none of the metabolites were considered good indicators of energy balance. The BHBA profiles in our study showed the same tendencies as the NEFA profiles, that OMC had lesser concentrations than CMC, but the differences were constant over the whole study period after calving. BHBA profiles generally have a later and flatter peak than NEFA (Busato et al., 2002; Nielsen et al., 2007). In the study by Andersen et al. (2004) feeding cows with low and high energy density, cows with low energy density showed a larger metabolic imbalance expressed as greater BHBA concentrations, which was opposite to what our study indicates.
According to the practical experience of Whitaker et al. (1983) optimum group means of BHBA concentrations ought to be under $1 \mathrm{mmol} / \mathrm{L}$ for cows in early lactation. The BHBA profile for CMC in our study exceeded 1 $\mathrm{mmol} / \mathrm{L}$ in the interval between 10 and $29 \mathrm{~d}$ postcalving, which is noteworthy and may indicate problems with subclinical ketosis. The insulin profiles were as expected, showing a sharp decrease postcalving, which is thought to reduce muscle and adipose uptake of glucose and facilitate the glucose uptake by the mammary gland. Insulin is suggested to play an important role partitioning energy in early lactation (van Knegsel et al., 2007). In our study we found a significant difference in the interval between 0 and $4 \mathrm{~d}$ postcalving in samples from February and March in which CMC had a lower nadir than OMC, followed by a rather similar increase over the following study period. Samples from October to December presented similar profiles, but there was no difference between $\mathrm{OMC}$ and $\mathrm{CMC}$. The reason for this seasonal difference is not obvious.

The blood glucose profiles from both organic and conventional cows were similar to each other in our study, and blood glucose concentration has actually been suggested to be a poor indicator of energy balance (Whitaker, 1997; McNamara et al., 2003). Hence, no conclusions about energy balance could be made based on glucose concentrations beyond that we had a good resemblance with glucose profiles from other studies 
Table 4. Estimated differences ${ }^{1}$ in blood metabolites and BCS in 899 cows from 20 organic and 20 conventional Swedish dairy farms

\begin{tabular}{|c|c|c|c|c|c|c|c|c|c|c|c|c|}
\hline \multirow{3}{*}{$\begin{array}{l}\text { Days } \\
\text { in milk }\end{array}$} & & & & & \multicolumn{4}{|c|}{ lnInsulin } & & & & \\
\hline & \multicolumn{2}{|c|}{ lnNEFA } & \multicolumn{2}{|c|}{$\ln B H B A$} & \multicolumn{2}{|c|}{ Spring } & \multicolumn{2}{|c|}{ Fall } & \multicolumn{2}{|c|}{ Glucose } & \multicolumn{2}{|c|}{ BCS } \\
\hline & Estimate & $95 \%$ CI & Estimate & $95 \%$ CI & Estimate & $95 \%$ CI & Estimate & $95 \%$ CI & Estimate & $95 \%$ CI & Estimate & $95 \%$ CI \\
\hline$>0$ & -0.11 & $-0.35,0.14$ & -0.06 & $-0.26,0.15$ & -0.10 & $-0.41,0.21$ & -0.04 & $-0.46,0.38$ & 0.03 & $-0.16,0.22$ & 0.06 & $-0.16,0.29$ \\
\hline $0-4$ & -0.15 & $-0.45,0.15$ & 0.06 & $-0.18,0.30$ & $0.49^{*}$ & $0.11,0.87$ & 0.10 & $-0.40,0.60$ & -0.04 & $-0.27,0.18$ & 0.05 & $-0.23,0.33$ \\
\hline $5-9$ & -0.23 & $-0.50,0.04$ & -0.18 & $-0.40,0.05$ & 0.17 & $-0.18,0.53$ & -0.19 & $-0.62,0.24$ & 0.16 & $-0.05,0.36$ & -0.01 & $-0.26,0.25$ \\
\hline $10-14$ & $-0.30^{*}$ & $-0.54,-0.05$ & $-0.25^{*}$ & $-0.45,0.04$ & 0.04 & $-0.27,0.35$ & -0.42 & $-0.86,0.02$ & 0.09 & $-0.10,0.28$ & 0.22 & $0.00,0.45$ \\
\hline $15-19$ & 0.07 & $-0.18,0.31$ & -0.17 & $-0.37,0.03$ & -0.09 & $-0.41,0.22$ & -0.27 & $-0.66,0.13$ & 0.02 & $-0.17,0.21$ & 0.12 & $-0.10,0.34$ \\
\hline $20-24$ & 0.15 & $-0.11,0.41$ & -0.10 & $-0.32,0.11$ & -0.06 & $-0.40,0.28$ & -0.15 & $-0.56,0.27$ & 0.06 & $-0.14,0.26$ & 0.04 & $-0.21,0.28$ \\
\hline $25-29$ & -0.08 & $-0.34,0.18$ & $-0.22^{*}$ & $-0.43,0.00$ & 0.14 & $-0.20,0.48$ & -0.11 & $-0.51,0.30$ & 0.11 & $-0.09,0.31$ & 0.23 & $-0.01,0.47$ \\
\hline $30-34$ & -0.12 & $-0.35,0.12$ & -0.14 & $-0.34,0.05$ & $-0.30^{*}$ & $-0.59,0.02$ & -0.42 & $-0.88,0.03$ & -0.04 & $-0.22,0.15$ & 0.03 & $-0.19,0.25$ \\
\hline$>34$ & -0.04 & $-0.25,0.17$ & -0.12 & $-0.30,0.06$ & -0.10 & $-0.36,0.17$ & -0.25 & $-0.61,0.10$ & 0.05 & $-0.11,0.22$ & 0.18 & $-0.01,0.37$ \\
\hline
\end{tabular}

${ }^{1}$ Differences were obtained from linear mixed model analyses as the estimate for organic minus the estimate for conventional. A significant difference $(P<0.05)$ is denoted with an asterisk $\left(^{*}\right)$. The models included management type, days in milk, and where applicable, breed, month of testing, housing, and parity. CI $=$ confidence interval.

Table 5. Estimated (Est.) main effects ${ }^{1}$ from linear mixed models of blood metabolites and BCS in 899 cows from 20 organic and 20 conventional Swedish dairy farms

\begin{tabular}{|c|c|c|c|c|c|c|c|c|c|c|c|c|c|c|c|c|c|c|c|}
\hline \multirow[b]{3}{*}{ Variable } & \multirow[b]{3}{*}{ Amount } & & & & & & & \multicolumn{6}{|c|}{ lnInsulin } & & & & & & \\
\hline & & \multicolumn{3}{|c|}{$\operatorname{lnNEFA}$} & \multicolumn{3}{|c|}{$\ln B H B A$} & \multicolumn{3}{|c|}{ Spring } & \multicolumn{3}{|c|}{ Fall } & \multicolumn{3}{|c|}{ Glucose } & \multicolumn{3}{|c|}{ BCS } \\
\hline & & Est. & $\mathrm{SE}$ & $95 \%$ CI & Est. & $\mathrm{SE}$ & $95 \%$ CI & Est. & $\mathrm{SE}$ & $95 \%$ CI & Est. & $\mathrm{SE}$ & $95 \%$ CI & Est. & $\mathrm{SE}$ & $95 \%$ CI & Est. & $\mathrm{SE}$ & $95 \% \mathrm{CI}$ \\
\hline \multirow{3}{*}{$\begin{array}{l}\text { Intercept } \\
\text { Breed }^{2}\end{array}$} & & 2.73 & 0.08 & $2.57,2.88$ & 0.14 & 0.09 & $-0.04,0.31$ & 2.06 & 0.10 & $1.86,2.26$ & 2.20 & 0.15 & $1.91,2.49$ & 2.39 & 0.08 & $2.23,2.56$ & 2.73 & 0.08 & $2.57,2.88$ \\
\hline & SRB & 0.26 & 0.04 & $0.18,0.35$ & - & - & - & - & - & - & - & - & - & - & - & - & 0.26 & 0.04 & $0.18,0.35$ \\
\hline & $\mathrm{SH}$ & Ref. & $\mathrm{NA}^{3}$ & NA & - & - & - & - & - & - & - & - & - & - & - & - & Ref. & NA & NA \\
\hline \multirow{5}{*}{$\begin{array}{l}\text { Month of } \\
\text { testing }\end{array}$} & February & - & - & - & 0.08 & 0.06 & $-0.03,0.20$ & - & - & - & - & - & - & 0.13 & 0.05 & $0.02,0.24$ & - & - & - \\
\hline & March & - & - & - & 0.09 & 0.06 & $-0.04,0.21$ & - & - & - & - & - & - & 0.20 & 0.06 & $0.09,0.32$ & - & - & - \\
\hline & October & - & - & - & -0.12 & 0.08 & $-0.28,0.03$ & - & - & - & - & - & - & 0.12 & 0.07 & $-0.02,0.27$ & - & - & - \\
\hline & November & - & - & - & -0.05 & 0.07 & $-0.19,0.09$ & - & - & - & - & - & - & 0.11 & 0.07 & $-0.02,0.25$ & - & - & - \\
\hline & December & - & - & - & Ref. & NA & NA & - & - & - & - & - & - & Ref. & NA & NA & - & & - \\
\hline \multirow[t]{2}{*}{ Housing } & Loose stall & - & - & - & -0.19 & 0.06 & $-0.32,0.06$ & - & - & - & - & - & - & - & - & - & - & & - \\
\hline & Tie stall & - & - & - & Ref. & NA & NA & - & - & - & - & - & - & - & - & - & - & & - \\
\hline \multirow[t]{3}{*}{ Parity } & 1 & - & - & - & -0.28 & 0.03 & $-0.35,0.22$ & 0.14 & 0.06 & $0.03,0.25$ & 0.22 & 0.08 & $0.07,0.38$ & 0.26 & 0.03 & $0.20,0.32$ & - & - & - \\
\hline & 2 & - & - & - & -0.10 & 0.04 & $-0.18,0.03$ & 0.09 & 0.06 & $-0.03,0.21$ & 0.04 & 0.08 & $-0.12,0.20$ & 0.04 & 0.03 & $-0.02,0.11$ & - & - & - \\
\hline & $3+$ & - & - & - & Ref. & NA & NA & Ref. & NA & NA & Ref. & NA & NA & Ref. & NA & NA & - & - & - \\
\hline
\end{tabular}


A
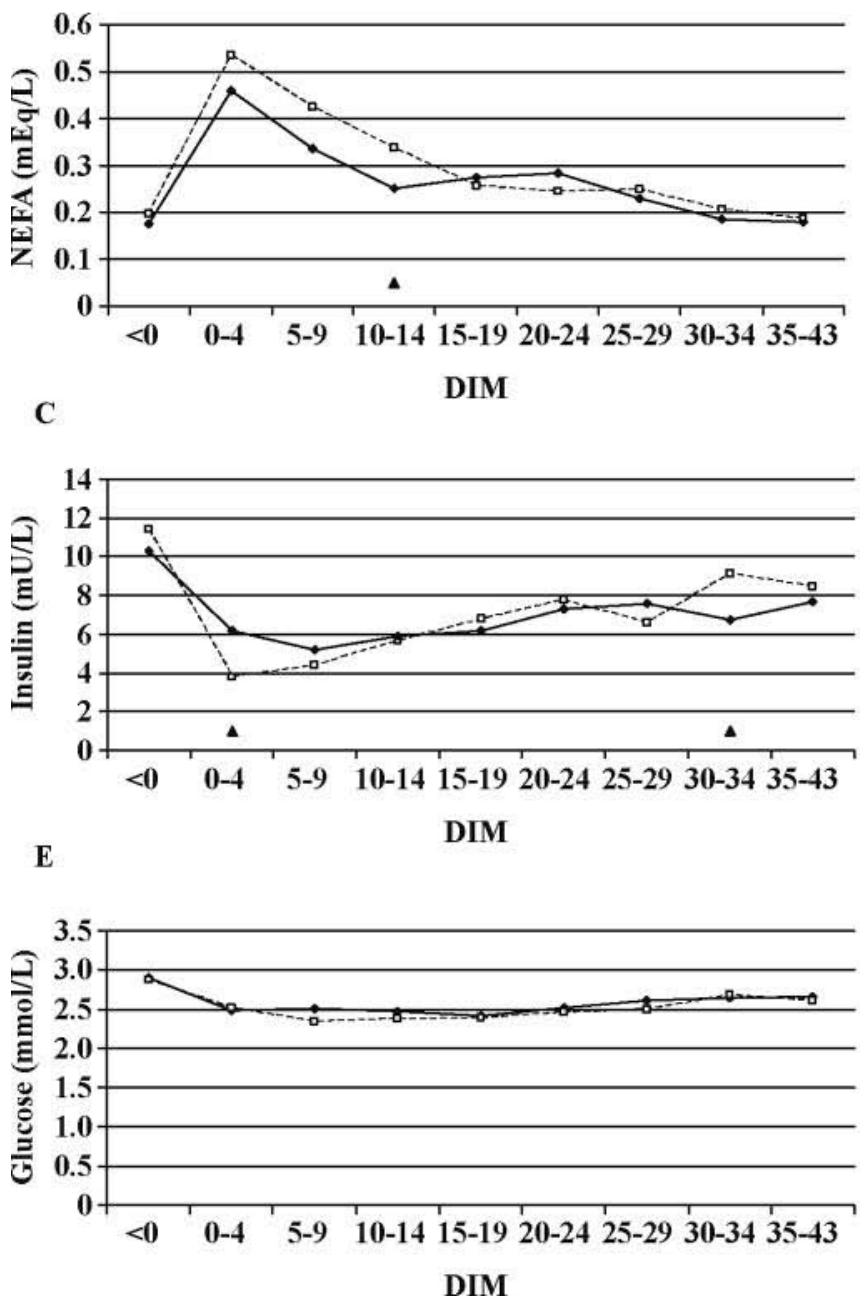

B
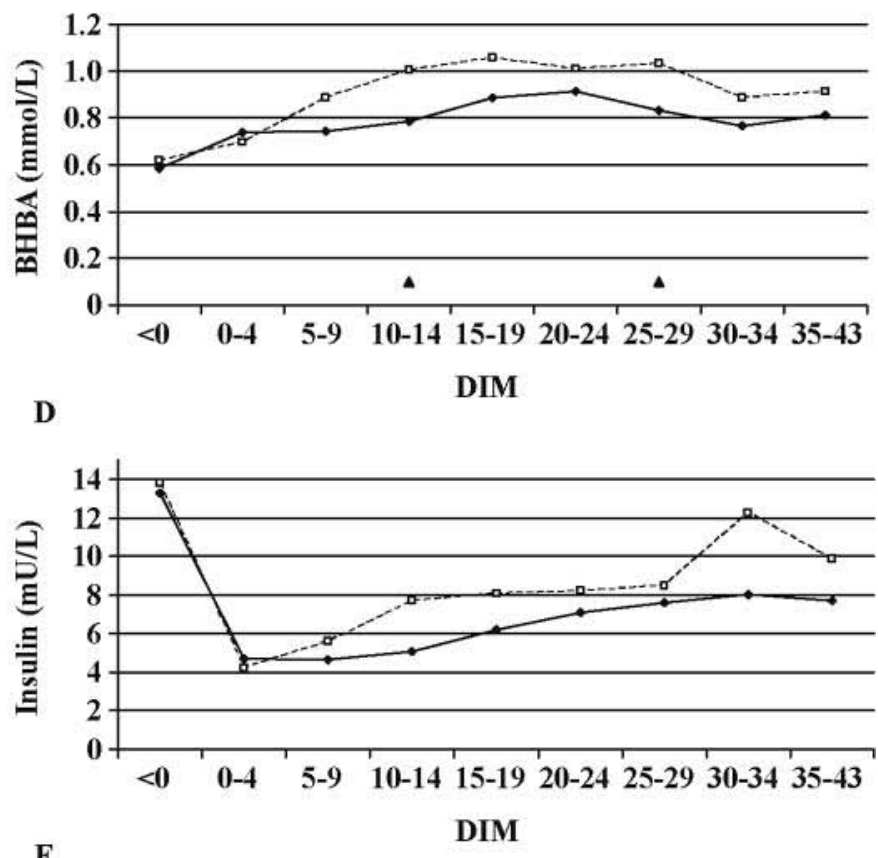

$\mathbf{F}$

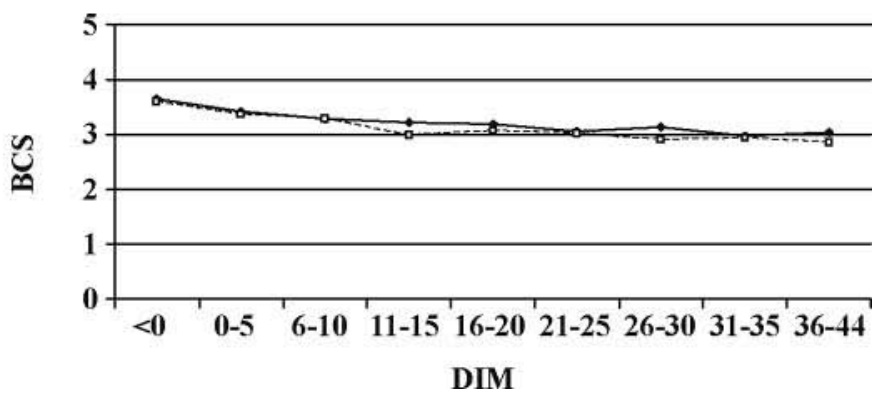

Figure 2. Least squares means (LSM) from linear mixed models of blood metabolites and BCS in 899 Swedish lactating dairy cows from 20 organically and 20 conventionally managed farms studied to determine metabolic profiles. All LSM are presented on the observed scale. A) NEFA, B) BHBA, C) insulin tested in February and March, D) insulin tested from October to December, E) Glucose, and F) BCS. Organically managed cows are represented by solid lines (- - ) and conventionally managed cows by dotted lines (---口---). Time points with a significant difference $(P<0.05)$ are denoted with $\boldsymbol{\Lambda}$.

(McNamara et al., 2003; Andersen et al., 2004). Making the glucose analyses cow-side was an advantage for the investigator due to practical reasons, and resemblance to glucose profiles from other studies assures the accuracy of the profiles.

The BCS profiles in our study were also similar to each other and did not differ between management groups. In the previously mentioned Swiss study by Roesch et al. (2005) no difference was found in median $\mathrm{BCS}$ at $30 \mathrm{~d}$ prepartum or $30 \mathrm{~d}$ postpartum between $\mathrm{OMC}$ and CMC. The authors did, however, find a greater loss in BCS for OMC compared with CMC between these points in time, speculated to originate from in- sufficient energy intake. Among other authors, Busato et al. (2002) showed that cows losing > 0.75 BCS points during the first 2 mo of lactation yield more milk, suggesting that mobilized body fat is used as an energy source for milk production. Considering the indications of more fat mobilization in CMC in our study, one could speculate that we should also find corresponding differences in BCS loss, which, however, was not the case. A drawback in our study may be that the integer-based scale according to Wildman et al. (1982) was used, which possibly introduced more misclassification bias than a more comprehensive scale would have done. That was, however, the scale frequently used at the 
Department of Clinical Sciences, SLU, Sweden, which the principal investigator was familiar with at the time of completing the study.

One difficult condition in large scale field studies is to obtain accurate feeding information compared with experimental settings. We chose to overlook this shortcoming because we considered it far more important to assess energy metabolism between organic and conventional herds with a large sample and under field conditions to complement existing knowledge received from experimental studies. Most Swedish dairy cow diets, however, are roughage-based, and grass/clover silage is the most common roughage used. This observation is valid for both types of farms, at least within the geographic area under study. Differences between organic and conventional feedstuffs are thus probably less pronounced in Sweden than in many other countries, where for instance corn-silage is more common in conventional systems. This is consistent with the smaller differences in vitamin and selenium content shown in Swedish bulk tank milk (Emanuelson and Fall, 2007) than in Danish bulk tank milk (Nielsen et al., 2004).

Another difficult condition was that all studied blood metabolites have been reported to exhibit some diurnal variation (Nielsen et al., 2003; Plaizier et al., 2005), although it is not always observed (Roesch et al., 2005). In our study the majority of samples were drawn in the morning, a few hours after feeding, and the remaining samples were drawn at approximately noon. The samples were drawn in roughly the same time interval in relation to feeding, and that is why we chose to overlook this potential confounding factor. Also, herds of both types were visited at these times and we had thus no reason to believe differential misclassification bias. On the other hand a degree of selection bias may be present in this study, as we could only enroll farms that agreed to participate. There was a larger interest in participating from the organic herds than from the conventional herds, which may have affected the comparisons although it is impossible to know in what direction. One could also argue that the study would have benefited from a larger sample size, to detect possible differences. The main point in this study, however, is that even if differences exist between organic and conventional herds, the differences are small.

\section{CONCLUSIONS}

Under Swedish conditions cows in organic and conventional dairy management differ little considering metabolic profiles, implying that organic management does not increase the risk for metabolic disturbances compared with conventional management. Further- more it means that $\mathrm{OMC}$ adapt their milk production to feeding.

\section{ACKNOWLEDGMENTS}

The authors thank the Swedish Dairy Association and the Swedish Research Council for Environment, Agricultural Sciences and Spatial Planning for financial support. The authors would also like to acknowledge Tove Fall, SLU for helpful discussions.

\section{REFERENCES}

Adewuyi, A. A., J. B. Roelofs, E. Gruys, M. J. M. Toussaint, and F. van Eerdenburg. 2006. Relationship of plasma nonesterified fatty acids and walking activity in postpartum dairy cows. J. Dairy Sci. 89:2977-2979.

Andersen, J. B., N. C. Friggens, T. Larsen, M. Vestergaard, and K. L. Ingvartsen. 2004. Effect of energy density in the diet and milking frequency on plasma metabolites and hormones in early lactation dairy cows. J. Vet. Med. A Physiol. Pathol. Clin. Med. $51: 52-57$.

Andersen, J. B., N. C. Friggens, K. Sejrsen, M. T. Sorensen, L. Munksgaard, and K. L. Ingvartsen. 2003. The effects of low vs. high concentrate level in the diet on performance in cows milked two or three times daily in early lactation. Livest. Prod. Sci. 81:119-128.

Busato, A., D. Faissler, U. Kupfer, and J. W. Blum. 2002. Body condition scores in dairy cows: Associations with metabolic and endocrine changes in healthy dairy cows. J. Vet. Med. A Physiol. Pathol. Clin. Med. 49:455-460.

Butler, S. T., A. L. Marr, S. H. Pelton, R. P. Radcliff, M. C. Lucy, and W. R. Butler. 2003. Insulin restores GH responsiveness during lactation-induced negative energy balance in dairy cattle: Effects on expression of IGF-I and GH receptor 1A. J. Endocrinol. 176:205-217.

Council of the European Communities. 1991. Council Regulation (EEC) No 2092/91 on organic production of agricultural products and indications referring thereto on agricultural products and foodstuffs. Counc. Eur. Communities, Brussels, Belgium.

Danell, B. 1982. Studies on lactation yield and individual testday yields of Swedish dairy cows. 2: Estimation of genetic and phenotypic parameters. Acta Agric. Scand. 32:83-92.

Dhiman, T. R., J. Kleinmans, N. J. Tessmann, H. D. Radloff, P. van Evert, and L. D. Satter. 1991. Effect of dietary forage:grain ratio on blood constituents in dairy cows. J. Dairy Sci. 74:26912695.

Emanuelson, U., and N. Fall. 2007. Vitamins and selenium in bulk tank milk of organic and conventional dairy farms. Page 35 in book of abstracts. 58th Annual Meeting of the European Association for Animal Production, Dublin, Ireland. Merkur Druck und. Kopier-Zentrum, Leipzig, Germany.

Grum, D. E., J. K. Drackley, R. S. Younker, D. W. LaCount, and J. J. Veenhuizen. 1996. Nutrition During the Dry Period and Hepatic Lipid Metabolism of Periparturient Dairy Cows. J. Dairy Sci. 79:1850-1864.

Hamilton, C., U. Emanuelson, K. Forslund, I. Hansson, and T. Ekman. 2006. Mastitis and related management factors in certified organic dairy herds in Sweden. Acta Vet. Scand. 48:11.

Hamilton, C., I. Hansson, T. Ekman, U. Emanuelson, and K. Forslund. 2002. Health of cows, calves and young stock on 26 organic dairy herds in Sweden. Vet. Rec. 150:503-508.

Hardeng, F., and V. L. Edge. 2001. Mastitis, Ketosis, and Milk Fever in 31 Organic and 93 Conventional Norwegian Dairy Herds. J. Dairy Sci. 84:2673-2679.

Ingvartsen, K. L., R. J. Dewhurst, and N. C. Friggens. 2003. On the relationship between lactational performance and health: Is it 
yield or metabolic imbalance that cause production diseases in dairy cattle? A position paper. Livest. Prod. Sci. 83:277-308.

Jorritsma, R. 2003. Negative energy balance in dairy cows as related to fertility. Thesis. Utrecht University, Utrecht, the Netherlands.

Kokkonen, T., J. Taponen, T. Anttila, L. Syrjala-Qvist, C. Delavaud, Y. Chilliard, M. Tuori, and A. T. Tesfa. 2005. Effect of body fatness and glucogenic supplement on lipid and protein mobilization and plasma leptin in dairy cows. J. Dairy Sci. 88:1127-1141.

McNamara, S., J. J. Murphy, M. Rath, and F. P. O'Mara. 2003. Effects of different transition diets on energy balance, blood metabolites and reproductive performance in dairy cows. Livest. Prod. Sci. 84:195-206.

Nielsen, J. H., T. Lund-Nielsen, and L. Skibsted. 2004. Danish Research Centre for Organic Farming. Higher antioxidant content in organic milk than in conventional milk due to feeding strategy. http://www.darcof.dk/enews/sep04/milk.html Accessed Feb. 12, 2008.

Nielsen, N. I., N. C. Friggens, T. Larsen, B. Andersen, M. O. Nielsen, and K. L. Ingvartsen. 2007. Effect of changes in diet energy density on feed intake, milk yield and metabolic parameters in dairy cows in early lactation. Animal 1:335-346.

Nielsen, N. I., K. L. Ingvartsen, and T. Larsen. 2003. Diurnal variation and the effect of feed restriction on plasma and milk metabolites in TMR-fed dairy cows. J. Vet. Med. A Physiol. Pathol. Clin. Med. 50:88-97.
Plaizier, J. C., A. M. Fairfield, P. A. Azevedo, A. Nikkhah, T. F. Duffield, G. H. Crow, R. Bagg, P. Dick, and B. W. McBride. 2005. Effects of monensin and stage of lactation on variation of blood metabolites within twenty-four hours in dairy cows. J. Dairy Sci. 88:3595-3602.

Roesch, M., M. G. Doherr, and J. W. Blum. 2005. Performance of dairy cows on Swiss farms with organic and integrated production. J. Dairy Sci. 88:2462-2475.

SAS Institute. 2004. Version 9.1.3. SAS Institute Inc., Cary, NC.

van Knegsel, A. T. M., H. van den Brand, E. A. M. Graat, J. Dijkstra, R. Jorritsma, E. Decuypere, S. Tamminga, and B. Kemp. 2007. Dietary energy source in dairy cows in early lactation: Metabolites and metabolic hormones. J. Dairy Sci. 90:1477-1485.

Vazquez-Anon, M., S. Bertics, M. Luck, R. R. Grummer, and J. Pinheiro. 1994. Peripartum liver triglyceride and plasma metabolites in dairy cows. J. Dairy Sci. 77:1521-1528.

Whitaker, D. A. 1997. Interpretation of metabolic profiles in dairy cattle. Cattle Pract. 5:57-60.

Whitaker, D. A., J. M. Kelly, and E. J. Smith. 1983. Subclinical ketosis and serum beta-hyroxybutyrate levels in dairy cattle. Br. Vet. J. 139:462-463.

Wildman, E. E., G. M. Jones, P. E. Wagner, R. L. Boman, H. F. Troutt, and T. N. Lesch. 1982. A dairy cow body condition scoring system and its relationship to selected production characteristics. J. Dairy Sci. 65:495-501. 